\title{
Implementasi Penilaian Hasil Belajar Siswa Berbasis Aplikasi Raport Digital (ARD) di MTs Negeri Kota Kupang
}

\author{
Muh. Amiruddin Salem ${ }^{1}$, Yusuf Ali Samad ${ }^{2 *}$ \\ ${ }^{1}$ Pendidikan Guru Madrasah Ibtidaiyah, Tarbiyah, Sekolah Tinggi Agama Islam, Kupang, Indonesia \\ ${ }^{2}$ MTs Negeri Kota Kupang, Kupang, Indonesia \\ Email: ${ }^{1}$ muh.amiruddinsalem@ gmail.com, ${ }^{2 *}$ yusufalisamad692@gmail.com
}

\begin{abstract}
Assessment of learning outcomes is an integral component in the implementation of education. The necessity to conduct an assessment of learning outcomes is emphasized in the Regulation of the Minister of Education and Culture Number 66 of 2013 concerning Educational Assessment Standards that these standards aim to ensure: (1) Planning of students is in accordance with the competencies achieved based on assessment principles, (2) Implementation of professional assessment of participants, open, educative, effective, efficient, and in accordance with the socio-cultural context, and (3) Reporting the results of participant assessments in an objective, accountable, and informative manner. manners. The approach used is qualitative. The type of research is case study. Data collection techniques using the method of observation, interviews, and documentation. The results obtained from this study are; 1) The Digital Report Card or ARD application is used to make it easier for teachers to process learning outcomes that have been achieved by students in the learning process. 2). In the process of inputting the assessment of student learning outcomes, $90 \%$ of teachers at MTs Negeri Kupang have been able to use the Digital Report Card (ARD) Application and 10\% are still in the process of assisting ARD operators. The input of grades is done online and is connected directly to the server at the school.
\end{abstract}

Keywords: Assessment of Learning Outcomes, Digital Raport Application (ARD)

\begin{abstract}
ABSTRAK
Penilaian hasil belajar merupakan komponen yang tidak terpisahkan dalam penyelenggaran pendidikan. Keharusan melaksana-kan penilaian hasil belajar ditegaskan dalam Peraturan Menteri Pendidikan dan Budaya Nomor 66 Tahun 2013 tentang Standar Penilaian Pendidikan bahwa standar penilaian bertujuan untuk menjamin: (1) Perencanaan peserta didik sesuai dengan kompetensi yang dicapai berdasarkan prinsip-prinsip penilaian, (2) Pelaksanaan penilaian peserta didik secara profesional, terbuka, edukatif, efektif, efisien, dan sesuai dengan konteks sosial budaya, serta (3) Pelaporan hasil penilaian peserta didik secara objektif, akuntebel dan informatif. Pendekatan yang digunakan adalah kualitatif. Jenis penelitiannya studi kasus. Teknik pengumpuan data menggunakan metode observasi, wawancara, dan dokumentasi. Hasil yang diperoleh dari penelitian ini adalah; 1) Aplikasi Rapor Digital atau ARD digunakan untuk mempermudah guru dalam mengolah nilai hasil belajar yang telah dicapai peserta didik dalam proses pembelajaran. 2). Dalam proses penginputan penilaian hasil belajar siswa sudah berjalan dengan baik, 90\% guru MTs Negeri Kota Kupang sudah bisa menggunakan Aplikasi Raport Digital (ARD) dan 10\% masih dalam proses pendampingan operator ARD. Penginputan nilai dilakukan secara online dan terhubung langsung dengan server disekolah.
\end{abstract}

Kata Kunci: Penilaian Hasil Belajar, Aplikasi Raport Digital (ARD)

\section{Pendahuluan}

harus mampu mengolah dan membuat laporan hasil Penilaian dalam kurikulum 2013 revisi guru dituntut belajar peserta didik secara deskriptif, objektif, untuk merencanakan serta melaksanakan penilaian informatif, dan akuntabel [1]. Menurut Hamalik hasil proses dan hasil belajar peserta didik secara utuh dan belajar adalah sebagai terjadinya perubahan tingkah menyeluruh. Meliputi penilaian sikap, penilaian laku pada diri seseorang yang dapat diamati dan diukur pengetahuan, dan penilaian keterampilan. Guru juga bentuk pengetahuan, sikap dan keterampilan. 
Perubahan tersebut dapat diartikan sebagai terjadinya menghasilkan data deskriptif berupa kata-kata tertulis peningkatan dan pengembangan yang lebih baik dari atau lisan dari orang atau perilaku yang dapat di sebelumnya dan yang tidak tahu menjadi tahu [2]. amati[5]

Berdasarkan observasi yang dilakukan peneliti, penilaian hasil belajar di MTs Negeri Kota Kupang 2.2. Data Penelitian

diambil dari tiga aspek kompetensi, yaitu afektif Data dalam penelitian ini bersumber dari dua jenis data, (sikap), kognitif (pengetahuan) dan psikomotorik yaitu data primer dan data sekunder. Data primer yang (keterampilan) [3]. Dengan mengacu pada konsep didapat melalui proses wawancara adalah data pembelajaran dan penilaian yang ada, maka penilaian mengenai bagaimana implementasi penilaian hasil hasil belajar harus mencakup ketiga komponen utama belajar siswa berbasis Aplikasi Raport Digital (ARD) tersebut dengan berbagai rinciannya serta menilai di MTs Negeri Kota Kupang. Sedangkan data sekunder pengembangan potensi peserta didik dalam berbagai dalam penelitian ini adalah data penunjang yang aspek dan bidangnya [4]. Dalam pengelolaan penilaian dikumpulkan berasal dari dokumen-dokumen yang hasil belajar pada aspek afektif (sikap), sebagian guru berkaitan dengan Aplikasi Raport Digital (ARD).

mengalami kesulitan penilaian pada teknik observasi karena kadang perilaku siswa tidak terekam akibat siswa dirumahkan untuk sementara karena Pandemi Covid 19, karena untuk observasi memerlukan pengamatan secara langsung oleh guru. Sebagian kecil guru MTs Negeri Kota Kupang merasa bahwa penilaian diri kurang maksimal dan beberapa guru menggunakan teknik penilaian antar teman sebagai tambahan atau pelengkap. Ada pula guru yang menggunakan penilaian antar teman hanya sekedar
untuk administrasi. Sebenarnya yang diharapkan dalam untuk administrasi. Sebenarnya yang diharapkan dalam
penilaian antar teman supaya peserta didik saling menilai temannya terkait dengan pencapaian kompetensi, sikap, dan perilaku keseharian peserta didik. Untuk penilaian kognitif beberapa guru kesulitan dalam melakukan penilaian seperti dalam pembagian waktu karena banyaknya jumlah siswa. Untuk penugasan di luar jam pembelajaran sebagian besar guru juga mengalami kendala, yakni penugasan pekerjaan rumah (PR). Problematikanya yaitu kadang siswa tidak mengerjakan PR, pekerjaan siswa tetapi dalam pengerjaannya lebih dominan orang tua. Sedangkan penilaian kompetensi keterampilan di MTs Negeri Kota Kupang yang sering digunakan guru adalah unjuk kerja. Namun, sebagian besar guru mengalami problematika yaitu tidak semua siswa memiliki kesempatan melakukan unjuk kerja. Banyaknya jumlah siswa dalam satu kelas berbanding terbalik dengan ketersediaan atau alokasi waktu. Hal ini mengakibatkan tidak semua siswa bisa menampilkan hasil pekerjaan karena pekerjaan siswa tidak selesai.

Dengan adanya pembaharuan teknologi berbasis digital pada penilaian. Aplikasi Rapor Digital (ARD) dapat membantu efektifitas dan efisiensi pengelolaan penilaian hasil pembelajaran di MTs Negeri Kota Kupang. Sehingga peneliti tertarik untuk melakukan penelitian tentang bagaimana implementasi penilaian hasil belajar siswa berbasis Aplikasi Raport Digital (ARD) di MTs Negeri Kota Kupang.

\section{Metode Penelitian}

\subsection{Pendektan dan Jenis Penelitian}

Pendekatan yang digunakan dalam penelitian ini adalah pendekatan kualitatif. Menurut Bogdan dan Taylor penelitian kualitatif adalah sebagai penelitian yang

\subsection{Teknik Pengumpulan Data}

Teknik pengumpuan data menggunakan metode observasi, wawancara, dan dokumentasi.

\subsection{Teknik Analisis Data}

Dalam penelitian ini, analisis data dilakukan dengan menggunakan metode deskripsi dengan teknik analisis induktif, dimana kesimpulan ditarik setelah melakukan ferifikasi data.

\section{Hasil dan Pembahasan}

3.1 Hasil Penelitian

3.1.1 Bagaimana Implementasi Aplikasi Rapor Digital (ARD) Dalam Penilaian Hasil Belajar Siswa Di MTs Negeri Kota Kupang.

Sejak tahun pelajaran 2018/2019 MTs Negeri Kupang sebagai salah satu sekolah yang berada di bawah naungan Kementerian Agama RI mengimplementasi proses pelaporan hasil belajar berbasis ARD. Berdasarkan wawancara dengan Kepala Madrasah MTs Negeri Kupang Implementasi pelaporan ARD sejalan dengan Surat Edaran/ Peraturan Menteri Agama RI No 5161 tahun 2018 yang bertujuan untuk meningkatkan efektifitas dan efisiensi pengelolaan penilaian hasil pembelajaran di madrasah serta menyesuaikan kebutuhan sistem pelaporan evaluasi pelajaran berbasis teknologi informasi [6].

Aplikasi Rapor Digital (ARD) adalah aplikasi yang mendata penilaian hasil belajar siswa secara online dibuat oleh pemerintah pusat dan digunakan oleh seluruh madrasah di Indonesia. ARD merupakan aplikasi yang wajib diterapkan dimadrasah khususnya MTs Negeri Kupang, dikarenakan yang membuat pemerintah pusat, maka ARD bisa dipantau langsung oleh pemerintah pusat terkait madrasah yang belum melakukan ARD atau madrasah yang sudah mengerjakan ARD.

Hasil wawancara dengan Musa Lea Lao, S.Pd selaku Kepala Madrasah di MTs Negeri Kupang, menyatakan bahwa :

"ARD Merupakan aplikasi wajib setiap madrasah, Selama beberapa tahun terakhir, evaluasi penilaian di MTsN Kota Kupang menggunakan sistem aplikasi online dan offline, yang terdiri dari aplikasi Woka Exambro, Jibas/Jibam dan E- 
Learning. Sedangkan untuk ARD sudah diterapkan Pengisian Aplikasi Rapor Digital (ARD) harus sejak tahun 2018 hingga sekarang. Dengan adanya dilakukan secara online di sekolah dengan ARD sangat membantu sekali untuk guru dalam menyambungkan ke server khusus dengan menyusun hasil pembelajaran siswa. Terlebih menggunakan alat ruter wifi. Pengerjaan ARD juga dimasa pandemi (covid-19)" bisa offline namun harus mengunduh templet yang ada Hal senada juga disampaikan oleh Febrinaldi, SS pada ARD. Proses pengunduhan templet ini harus selaku Guru Mata Pelajaran Bahasa Arab di MTs online dan mempermudah guru untuk mengerjakan Negeri Kupang, mengatakan bahwa ; penginputan nilai secara offline. Ketika templet nilai "mengatasi guru yang gaptek yaitu perlu adanya sudah terisi, kemudian templet tersebut harus di upload bimbingan secara bertahap dan berkala sehingga kembali ke ARD dengan sistem online. Berdasarkan guru tidak kesulitan dalam melakukan penginputan Hasil wawancara dengan guru MTs Negeri Kupang nilai di ARD tersebut"

Berdasarkan surat keputusan dari Dirjen Pendis, seluruh madrasah diwajibkan untuk menggunakan Aplikasi Raport Digital (ARD) sebagai wadah untuk pengelolaan penilaian hasil belajar siswa. Berdasarkan observasi yang dilakukan peneliti, Aplikasi Rapor Digital (ARD) sudah disosialisasikan di MTs Negeri Kupang sejak tahun 2018, namun belum sepenuhnya diterapakan karena perlu penyempurnaan dan Berdasarkan paparan data hasil wawancara diatas, disosialisasi kembali dengan seluruh guru yang ada di maka dapat disimpulkan bahwa Implementasi Aplikasi MTs Negeri Kupang. Seluruh guru dibimbing untuk Rapor Digital (ARD) dalam penilaian hasil belajar mengisi setiap kolom yang ada di ARD. Untuk siswa di MTs Negeri Kota Kupang sudah berjalan sejak mengatasi guru yang gagap dalam hal teknologi maka Tahun Pelajaran 2018/2019 dan sudah disosialisasikan. dibutuhkan pelatihan dan pendampingan. Sebagaimana Dalam proses penginputan penilaian hasil belajar siswa hasil wawancara dengan Musa Lea Lao, S.Pd selaku sudah berjalan dengan baik. Penginputan nilai di Kepala Madrasah di MTs Negeri Kupang, menyatakan Aplikasi Raport Digital (ARD) guru MTs Negeri bahwa :

Kupang melakukan secara online disekolah sehingga

"Dengan cara mensosialisasikan aturan-aturan memudahkan guru dalam penginputan nilai karena tentang penggunaan ARD serta menyelenggarakan terhubung langsung dengan server disekolah. workshop/ pelatihan penggunaan ARD. Guru yang Sedangkan guru-guru yang belum bisa mengoperasikan kurang mahir dalam bidang IPTEK akan diberi ARD untuk pengisian nilai akan didampingi oleh perhatian dan pendampingan khusus dengan Ahli/operator madrasah.

melibatkan tenaga-tenaga ahli dalam proses

evaluasi penilaian, pengisian ARD, sampai pada 3.1.2 Bagaimana Kelebihan Dan Kekurangan proses pencetakan ARD”.

MTs Negeri Kupang khususnya masih memiliki sebagian guru yang kurang mahir dalam mengoperasikan aplikasi ARD. Dengan adanya Proses implementasi Aplikasi Rapor Digital (ARD) kecanggihan teknologi saat ini mengharuskan guru dalam penilaian hasil belajar di MTs Negeri Kupang yang kurang mahir dalam teknologi wajib Tahun Pelajaran 2020/2021 memiliki beberapa meningkatkan kemampuannya dalam bidang teknologi. kelebihan serta kekurangan. Sesuai dengan SK Dirjen Namun memang butuh pendampingan secara khusus Pendis No 5161 Tahun 2018 bahwasanya ARD untuk menguasai teknologi dengan mudah. memudahkan pekerjaan guru untuk melakukan Sebagaimana hasil wawancara dengan Ramadan penilaian. Begitu pula beberapa kelebihan ARD yang di Mansyur, S.Pd selaku Operator di MTs Negeri Kupang, implementasikan MTs Negeri Kupang. Beberapa guru menyatakan bahwa:

MTs Negeri Kupang menyatakan bahwa, ARD adalah

"Untuk mengatasi guru yang kurang mahir yaitu aplikasi yang mempermudah pengerjaan guru dalam dengan cara melakukan pendampingan, biasanya penginputan nilai hasil belajar siswa. Karena dalam saya selaku operator turun langsung mendamping ARD bentuk pengisian nilainya lebih ringkas jika guru-guru untuk mengoperasikan ARD tersebut. dibandingkan dengan aplikasi rapor sebelumnya yang Tapi Alhamdulilah sejauh ini proses implementasi digunakan di MTs Negeri Kupang.

berjalan lancar. 90\% guru di madrasah khususnya Berdasarkan hasil wawancara dengan Jumadin M. guru di MTsN Kota Kupang mampu Natsir, S.Pd selaku Guru Mata Ilmu Pengetahuan Alam mengoperasikan ARD”.

Berdasarkan observasi yang dilakukan, beberapa guru memang ada yang kurang mahir dalam mengoperasikan laptop atau komputer sehingga mereka minta bantuan kepada operator atau bahkan guru lain yang dirasa sanggup dalam pengoperasian laptop/komputer.

di MTs Negeri Kupang., menyatakan bahwa:

1. Aplikasinya sangat mudah untuk digunakan

2. Bisa diakses dimanapun dan kapanpun

3. Pengkonversian nilai secara otomatis sehingga guru tidak lagi melakukan perhitungan secara manual

DOI: $10.54259 /$ satesi.v1i2.40

Lisensi: Creative Commons Attribution 4.0 International (CC BY 4.0) 
Hal yang sama juga disampaikan oleh Ramadan Mansyur,S.Pd selaku operator di MTs Negeri Kupang, menyatakan bahwa :

1. Dapat diakses dimana saja (online)

2. Dapat dikerjakan dalam waktu yang singkat

3. Jika terjadi kekeliruan dapat diakses kembali

4. Lebih efektif dan efisien

Berdasarkan data yang diperoleh, Rapor pada Aplikasi Raport Digital (ARD) yang sederhana membantu para wali murid untuk mengetahui kompetensi yang dicapai oleh putra-putrinya dengan mudah. Adanya laporan hasil belajar peserta didik juga dapat mengetahui sejauh mana tingkat keberhasilannya dalam melaksanakan pembelajaran pada tahapan satu semester. Dengan adanya laporan hasil belajar, setiap orang tua akan tau bagaimana langkah yang akan diambil selanjutnya untuk mempertahankan ataupun meningkatkan semangat belajar putra-putrinya

Hasil wawancara dengan Siti Maimuna, S.Pd selaku Guru Mata Pelajaran Fiqih MTs Negeri Kupang, menyatakan bahwa:

"Dalam ARD sudah ada deskripsinya setiap mata pelajaran, mulai dari penilaian sikap, pengetahuan, dan keterampilan. Sehingga orang tua bisa mengetahui sejauh mana hasil belajar putraputrinya selama satu semester. Sehingga membantu orang tua untuk memotivasi anaknya untuk belajar lebih giat lagi.

Aplikasi Raport Digital (ARD) merupakan sebuah sistem yang baru, sehingga membutuhkan penyesuaian dikarenakan guru-guru masih belum familiar, akan tetapi ketika guru-guru sudah mengenalnya, pasti akan merasa lebih mudah dalam pengerjaannya. Penilaian keterampilan dalam Aplikasi Raport Digital (ARD) tidak perlu mengisi secara keseluruhan, untuk itu nilainya benar-benar riil. Dalam data dokumentasi, pengisian nilai pada Aplikasi Raport Digital (ARD) tidak terlalu rumit, semua pengisian kolom nilai kembali pada muatan mata pelajaran. Berasarkan hasil wawancara dengan Febrinaldi, SS penilaian hasil belajar siswa di MTs Negeri Kota selaku Guru Mata Pelajaran Bahasa Arab di MTs Kupang sebenarnya tidak terlalu mencolok. Cuma Negeri Kupang, mengatakan bahwa ;

"Aplikasi ini mempermudah guru untuk mengisi nilai hasil pembelajaran siswa dan pengarsipan. Karena sangat baru dengan pengalaman guru yang baru, tentu penerapan aplikasi ini mempunyai banyak kendala.

Berdasarkan observasi, Aplikasi Raport Digital (ARD) server di sekolah, hal ini yang menjadi kendala dalam tidak terjadi lagi. Sedangkan kelebihannya adalah lebih menginput data. Jika server digunakan lebih dari 5 guru memudahkan guru dalam proses mengisi nilai hasil yang terhubung, maka server juga akan mengalami pembelajaran siswa dan pengarsipan, dapat diakses gangguan. Sistem pengerjaan secara online juga dimana saja secara (online), dapat dikerjakan dalam membuat guru harus terampil dalam penggunaan waktu yang singkat, jika terjadi kekeliruan dapat komputer atau laptop.

Berdasarkan hasil wawancara dengan Musa Lea Lao, per S.Pd. selaku kepala Madrasah, mengatakan bahwa ;

"Selama beberapa tahun terakhir, evaluasi ada deskripsinya setiap mata pelajaran, mulai dari penilaian di MTsN Kota Kupang menggunakan penilaian sikap, pengetahuan, dan keterampilan. sistem aplikasi online dan offline, yang terdiri dari aplikasi ARD, Woka Exambro, Jibas/Jibam dan ELearning. Kendala yang dihadapi selama ini adalah jaringan internet yang tidak stabil sangat serta beberapa guru-guru yang sudah tua yang tidak bisa mengoperasikan ARD sehingga dibantu oleh guru-guru lain dan juga dibantu langsung oleh operator disekolah".

Setiap sistem yang baru pasti memiliki kekurangan dan Negeri Kupang. Berdasarkan obeservasi yang peneliti kukan, MTs Negeri Kupang masih belum bisa dikarenakan sistem ARD yang belum sempurna dan beberapa kendala yang dihadapi, kemudian penerapan diadakannya sosialisasi ulang oleh pihak Kemenag Kota Kupang (Bidang Pendis) di MTs Negeri Kupang pada awal ajaran 2019/2020.

Natsir, S.Pd selaku Operator Madrasah, mengatakan

1. Kekurangan dari ARD yaitu belum adanya automatisasi dalam pendeskripsian nilai yang diinput serta pembatasan jumlah karakter huruf yaitu sebanyak 100 karakter

2. Belum adanya fitur yang memisahkan alamat

. Dalam pembuatan deskripsi nillai, terkadang ada beberapa guru yang keliru dalam memberi predikat nilai $A, B$ atau $C$

komplain dari orang wali yang ada pada kolom tanda tangan di bagian akhir rapor.

harapan kedepannya dalam menu ARD bisa tersedia orang tua, siswa dan wali, automatisasi dalam pendeskripsian nilai yang diinput serta pembatasan jumlah karakter huruf yaitu sebanyak 100 karakter, serta ketelitian guru dalam melakukan penginputan diakses kembali, lebih efektif dan efisien, pengkonversian nilai secara otomatis sehingga guru tidak lagi melakukan perhitungan secara manual dan

DOI: $10.54259 /$ satesi.v1i2.40 tempat tinggal sampai dengan nama orang tual 
Sehingga orang tua bisa mengetahui sejauh mana hasil belajar putra-putrinya selama satu semester.

\subsection{Pembahasan}

Kehidupan manusia di era digital akan selalu berhubungan dengan teknologi. Teknologi pada hakikatnya adalah proses untuk mendapatkan nilai tambah dari produk yang dihasilkannya agar bermanfaat. Teknologi telah mempengaruhi dan mengubah manusia dalam kehidupannya sehari-hari, sehingga jika sekarang ini gagap teknologi maka akan terlambat dalam menguasai informasi, dan akan tertinggal pula untuk memperoleh berbagai kesempatan maju. Orang-orang yang berkepentingan dengan pendidikan dituntut memiliki kemampuan memahami teknologi sesuai dengan kebutuhannya atau melek teknologi yang disebut juga memiliki literasi teknologi, karena akan berperan dalam kehidupan masa kini dan masa yang akan datang [7].

Berdasarkan hasil penelitian, Implementasi ARD di Implementasi ARD di MTs Negeri Kota Kupang MTs Negeri Kota Kupang dilaksanakan pada semester dilaksanakan pada semester ganjil tahun pelajaran ganjil tahun pelajaran 2018/2019 dengan melibatkan 2018/2019 dengan melibatkan operator dan guru. operator dan guru. Aplikasi Rapor Digital atau ARD Aplikasi Rapor Digital atau ARD digunakan untuk digunakan untuk mempermudah guru dalam mengolah mempermudah guru dalam mengolah nilai hasil belajar nilai hasil belajar yang telah dicapai peserta didik yang telah dicapai peserta didik dalam proses dalam proses pembelajaran. Dalam proses penginputan pembelajaran. Dalam proses penginputan penilaian penilaian hasil belajar siswa sudah berjalan dengan hasil belajar siswa sudah berjalan dengan baik, $90 \%$ baik, dari 50 Guru MTs Negeri Kota Kupang 45 guru guru MTs Negeri Kota Kupang sudah bisa sudah bisa menggunakan Aplikasi Raport Digital menggunakan Aplikasi Raport Digital (ARD) dan 10\% (ARD) dan 5 guru masih dalam proses pendampingan masih dalam proses pendampingan operator ARD. operator ARD. Dalam proses implementasi Aplikasi Dalam proses implementasi Aplikasi Raport Digital Raport Digital (ARD) guru MTs Negeri Kupang (ARD) guru MTs Negeri Kupang melakukan secara melakukan secara online disekolah, sehingga online disekolah, sehingga memudahkan guru dalam memudahkan guru dalam penginputan nilai karena penginputan nilai karena terhubung langsung dengan terhubung langsung dengan server. Sedangkan guru- server. Sedangkan guru-guru yang belum bisa guru yang belum bisa mengoperasikan ARD untuk mengoperasikan ARD untuk pengisian nilai akan pengisian nilai akan didampingi oleh Ahli/operator didampingi oleh Ahli/operator madrasah.

\section{madrasah.} Penerapan dan pengembangan teknologi informasi dan Digital (ARD) Dalam Penilaian Hasil Belajar Siswa di komunikasi dalam pembelajaran adalah salah satu MTs Negeri Kota Kupang yaitu; belum tersedianya langkah strategis dalam menyongsong masa depan fitur yang memisahkan alamat tempat tinggal orang tua, pendidikan. Pemanfaatan teknologi informasi dan siswa dan wali, automatisasi dalam pendeskripsian nilai komunikasi dalam pembelajaran bukan sekedar yang diinput serta pembatasan jumlah karakter huruf mengikuti trend global melainkan merupakan suatu yaitu sebanyak 100 karakter, serta ketelitian guru dalam langkah strategis di dalam upaya meningkatkan akses melakukan penginputan agar lebih teliti lagi sehingga dan mutu layanan pendidikan kepada masyarakat pada kesalahan-kesalahan berupa penginputan masa kini dan masa yang akan datang. Teknologi nama/identitas, alamat dan lainnya tidak terjadi lagi. informasi dan komunikasi masa yang akan datang perlu Sedangkan kelebihannya adalah lebih memudahkan dikembangkan mengarah pada terwujudnya sistem guru dalam proses mengisi nilai hasil pembelajaran pendidikan terpadu yang dapat membangun bangsa siswa dan pengarsipan, dapat diakses dimana saja yang mandiri, dinamis dan maju. [4].

Adanya impelementasi Aplikasi Rapor Digital (ARD) singkat, jika terjadi kekeliruan dapat diakses kembali, di MTs Negeri Kupang mengakibatkan munculnya lebih efektif dan efisien, pengkonversian nilai secara beberapa kelebihan dan kekurangan. Implementasi otomatis sehingga guru tidak lagi melakukan Aplikasi Rapor Digital (ARD) Dalam Penilaian Hasil perhitungan secara manual dan ada deskripsinya setiap Belajar Siswa di MTs Negeri Kota Kupang yaitu; mata pelajaran, mulai dari penilaian sikap, belum tersedianya fitur yang memisahkan alamat pengetahuan, dan keterampilan. Sehingga orang tua tempat tinggal orang tua, siswa dan wali, automatisasi bisa mengetahui sejauh mana hasil belajar putradalam pendeskripsian nilai yang diinput serta putrinya selama satu semester. 


\section{Referensi}

Jurnal Kependidikan, $\quad 6(1)$ https://doi.org/https://doi.org/10.24090/jk.v6i1.16

[1] E Mulyasa, Implementasi Kurikulum 2013 Revisi dalam Era Revolusi Industri 4.0, Jakarta: Bumi Aksara, 2018.

[2] Hamalik, Oemar, Kurikulum dan Pembelajaran. Jakarta: Sinar Grafika, 2008.

[3] Sugiyono, Metode Penelitian Kuantitatif, Kualitatif, dan $R \& D$, Bandung: Alfabeta, 2016

[4] Khusnuddin, K. (2018). Model Spreadsheet Excel Aplication sebagai Pengolahan Hasil Belajar Peserta Didik dalam Penilaian Kurikulum 2013.
[5] Direktorat Jenderal Pendidikan Islam Kementerian Agama Republik Indonesia, 2018 Panduan Penggunaan Aplikasi Raport Digital (Untuk Operator Madrasah dan Guru Madrasah MTs) (Jakarta: Kemenag)

[6] Mulyadi, Evaluasi Pendidikan Pengembangan Model Evaluasi Pendidikan Agama Di Sekolah, UIN-Maliki Press, 2010

[7] Munir, Pembelajaran Digital. Bandung: Alfabeta, 2017. 